\title{
The legacy of Coalition: fear and loathing in Conservative politics, 1922-1931
}

\author{
Stuart Ball
}

\begin{abstract}
The split over the coalition in October 1922 caused long-term disunity in the Conservative Party, and the distinction between pro- and anti-coalitionists remained the most significant fault-line in Conservative politics for the next nine years. The new leadership and the majority of backbench MPs constantly suspected the former coalitionists of plotting to reverse the verdict of 1922. The legacy of bitterness and distrust was a crucial factor in the key events of the period, including the aftermath of the 1923 election defeat, the formation of the 1924 cabinet, the 'cruiser crisis' of 1925, the Irwin Declaration crisis of 1929, and the attacks on Baldwin's leadership in 1930-31.
\end{abstract}

\section{KEYWORDS}

Baldwin, Birkenhead, Austen Chamberlain,Churchill, Coalition, Conservative Party

The fall of the Lloyd George Coalition was the formative event in Conservative politics between the wars, and it cast a long shadow. The rejection of coalition had profound consequences for the outlook and ethos of the Conservative Party, and its positioning in British politics. ${ }^{1}$ The opponents of the Coalition saw the decision of October 1922 as vital to the survival and integrity of the Party, and any hint of reversing it produced a disproportionate reaction. The Coalition had been overthrown by a rebellion from within the Conservative ranks which, like all forms of civil war, left a bitter legacy. It was never forgotten on which side anyone had taken their stand, and the victors were always unsure about the permanence of the outcome and unconvinced of the reliability of the losers. The events of October 1922 broke some careers and elevated others, creating a new set of leading figures who owed their eminence to the outcome of that crisis, and whose position was legitimised by the paramountcy of their interpretation of it. For these reasons, Conservative politics for nearly a decade afterwards were viewed through this prism, and shaped by its distorting effects.

The division in the Conservative Party was created during the year before the Parliamentary 
Party rejected the continuation of the Coalition by 185 votes to 88 at the Carlton Club meeting on 19 October 1922. The verdict did not just repudiate the strategy of an electoral alliance with Lloyd George's wing of the Liberal Party, it also swept out of office the Conservative leader, Austen Chamberlain, and the other prominent cabinet ministers who had supported the Coalition. Whilst they nursed their grievances in the wilderness, a new leadership group was established in the Conservative cabinet formed by the incoming Prime Minister, Andrew Bonar Law. For the first time since the split over the repeal of the Corn Laws in 1846, the Conservative Party had two rival sets of leaders; also mirroring 1846, the ousted leaders included many big names but relatively few backbenchers, and were regarded with a good deal of antagonism by the majority of their former followers. This historical parallel could only make Conservatives alarmed, for the rupture over the Corn Laws had led to several decades of marginalisation. They also had a much more recent example of the dangers of disunity to concentrate the mind: the decline of the Liberal Party into factionalism and futility since its split in 1916. These factors acted as moderating constraints upon Conservative divisions after 1922, and they were reinforced by the powerful traditions of unity, loyalty, civility and pragmatism which formed part of Conservative political culture. There was no open warfare between the two camps, no fragmentation of the constituency associations (a marked feature of the Liberal decay), and no fratricidal competing candidates in the general elections. ${ }^{2}$ The absence of these problems was the reason why the Conservative Party was not endangered by the split of 1922, and was able to achieve considerable electoral success during the rest of the inter-war period. However, it was not the case that there was no damage at all, or that its effects were limited only to the 15 months of disunity from October 1922 to January 1924. There were considerable tensions, resentments and insecurities, and a legacy of suspicion which tainted many of the interactions within the Party for a further eight years after the public reunion of 1924.

This did not just affect the most prominent leaders on each side: Bonar Law (for the few months left to him) and Baldwin of the anti-coalitionists; Austen Chamberlain, the Earl of Birkenhead, Sir Robert Horne, Earl Balfour and Sir Laming Worthington-Evans of the coalition supporters. It had a lasting impact even on the relatively junior figures involved, and thus when Leslie Scott (the Attorney-General in 1922) was a possible candidate for the Speakership in 1928, he was blocked by the Chief Whip's telling observation that he was 'not very popular with our people (they haven't forgotten the break up of the Coalition)'. 3 Even quite minor coalitionist MPs, such as Warden Chilcott or Oliver Locker-Lampson (who had been Austen Chamberlain's PPS) had a black mark against them for the rest of their careers. ${ }^{4}$ These antagonisms lasted, and they did not run in only one direction; when considering Leslie Wilson, who had been Chief Whip in 1922, as a possible Party Chairman eight years later, Bridgeman noted the main drawback was that 'the 
old Coalitioners hate him. ${ }^{5}$ During the months following the fall of the Coalition, Austen Chamberlain took pleasure in the plight of Sir Arthur Griffith-Boscawen, one of the two Conservative cabinet ministers in the House of Commons to oppose continuing the Coalition, who lost his seat in the 1922 general election and was unsuccessful in a by-election in March 1923. ${ }^{6}$ However, whilst 'out and out wishing for Boscawen's defeat', ${ }^{7}$ Chamberlain may have been unaware that the Independent Conservative candidate who was the crucial spoiler in the by-election was financed by Locker-Lampson. ${ }^{8}$ Antagonism and suspicion was voiced most frequently by the anti-coalitionists, partly because they were much more numerous, and partly because - as the ones in insecure ascendancy - they had most to lose. However, if fear (or its companion, paranoia) emanated from the anti-coalition side alone, bitterness was the province of the ousted coalitionists, whilst loathing was prevalent on both sides, sometimes concealed and sometimes openly vented.

The Carlton Club meeting revealed that the supporters of continued coalition were the minority, and their numbers shrank further in the following weeks. ${ }^{9}$ The securing of a purely Conservative working majority validated Law's strategy and meant that his government would continue, and after this some MPs quietly drifted back to the fold. In addition, the relatively small number of seats lost in 1922 concealed a much greater turnover in the Parliamentary Party. Only 233 of the 342 MPs elected in 1922 had sat in the previous House, whilst 111 (nearly one-third) were newcomers. The latter were likely to have accepted the fall of the Coalition as right and necessary, not least because they had won their seats following it, whilst it is very probable that those who voted for coalition at the Carlton Club were a disproportionate element of the departed. A more definite indication of the size of the coalitionist group was the 49 MPs present at the dinner held in honour of Austen Chamberlain on 30 November. ${ }^{10}$ However, some of these were probably motivated mainly by feelings of loyalty, and it is clear that very few were eager to continue the fight. In reality, the strength and importance of the pro-coalition group lay in its heavyweight figures rather than its numbers; it was always a matter of chiefs with relatively few Indians. For this reason, the discussion which follows deals with the former coalitionists mainly in terms of this cadre of leaders, whilst the anti-coalitionists were a much broader spectrum. They included the newly-promoted cabinet, the new generation of junior ministers and most of the backbenchers.

Given such broad support for the anti-coalition stance, and its confirmation by the laurels of victory in 1922, it might seem surprising that the issue of coalition was not dead and buried, or that the future course of the Conservative Party should ever again be in doubt. That this was far from the case was due to four reasons. First, the prestige and experience of the ousted leaders contrasted pointedly with that of their replacements, apart from Law and the Foreign Secretary who had continued in office from the Coalition, Lord Curzon. Second was the insecurity of the new 
leadership, who were prone to looking over their shoulders and seeing conspirators huddled in corners plotting against them. ${ }^{11}$ The third factor was the uncertain electoral situation due to the unprecedented three-party rivalry and its tendency to produce hung parliaments in which the Liberals held the balance. In particular, the coalitionists interpreted the 1922 election result in a quite different way: they noted that nearly two-thirds of voters had polled against the Conservative Party, and saw this as evidence of the dangers of standing as a party alone. On their reading, the outcome was proof of the correctness of their strategy; Law's majority was due to luck in the way

in which the electoral system had operated, and was no sound basis for the future. ${ }^{12}$ Finally, there was the unfamiliar and vastly increased mass electorate, and the related phenomenon of the rapid rise of the Labour Party; the first led to doubt and insecurity, the second to alarm and the quest for a response. Views on this varied, and in general the anti-coalitionists emphasised the need for a 'positive alternative', by which they meant tariff reform. This was partly because they felt that the Coalition had proven the futility of relying upon negative anti-Socialism, and partly due to the commitment of many Conservatives to Joseph Chamberlain's vision of a united Empire closely linked to a prosperous mother country. However, to achieve this goal the protectionist programme required taxes on imports of food, and so made alliance with the staunchly free-trade Liberals impossible. For this reason, protectionism became identified with the independence and autonomy of the Conservative Party, and its advocates became a powerful bloc of support for the anticoalitionists - even when Baldwin in 1927-29 refused to move forward by extending the limited protectionism of the Safeguarding Act to the iron and steel industries.

The most sensitive and potentially dangerous period was that immediately following the fall of the Coalition. From October 1922 until the leading ex-coalitionists were invited to join the shadow cabinet in January 1924, there existed an alternative leadership in exile who stood for, and were a constant reminder of, a different political strategy. This period falls into four phases: from the Carlton Club meeting to the outcome of the general election in November 1922, from then until Bonar Law's retirement in May 1923, from Baldwin's succession to the Premiership until the defeat in the general election of December 1923, and finally the confused period between that and the two events of January 1924: the return of the coalitionists to the Conservative front bench, and the taking of office by the first Labour government.

For much of this time, the former coalitionists were content to sit on the sidelines, as they 
were convinced that the new government would last 'a short time only', after which the Party would return to its senses under 'its proper leaders'. ${ }^{13}$ During the first phase, the coalitionists were partly recovering from the shock of being dispossessed of the power which they had come to take for granted, and partly constrained by their tactical dilemma. With a general election under way, any raking over the coals would seem to be damaging the Party's electoral fortunes for reasons of personal spite. Austen Chamberlain was by nature conventional and cautious, and his Birmingham base made him more aware of what limited latitude the grass-roots would tolerate. Like other west of Scotland MPs, the former Chancellor of the Exchequer, Sir Robert Horne, was more focused upon the external threat of Labour than internal recriminations; as a relative newcomer, only having entered the Commons in 1918, he also carried less weight. The other leading coalitionists were peers, and Lords Balfour and Crawford were restrained as much by character as by the lingering convention that members of the upper House did not actively campaign in the elections to the lower. Neither factor affected the other peer, the Earl of Birkenhead, who had ridden high and hard in the Coalition as Lord Chancellor, and was considered to have contributed much to its cynical opportunism. He was by far the most outspoken of the fallen leaders during this first phase, and his attacks were deeply resented by the anti-coalitionists. ${ }^{14}$ However, this was no more than sniping from the sidelines, and the coalitionists were careful to do nothing to cause direct electoral damage.

To their surprise, and possibly that of Law and his new cabinet, the result of the election was an overall majority for the Conservative Party on its own, with 342 MPs; Labour had advanced considerably to $142 \mathrm{MPs}$, and there were 62 Liberal followers of Asquith and 53 of Lloyd George. ${ }^{15}$ It was clear from this that the Law government would be in office for some time (Austen Chamberlain thought for three or four years ${ }^{16}$ ), and that any undermining of the first Conservative ministry since 1905 would be unacceptable to the rank and file on the backbenches and in the constituencies. There would have to be a period of delay before there could be a reunion, although it was known that Law wanted to accomplish this as soon as possible, as he shared the widespread view that the front bench was weak in administrative experience and debating power. The awareness that the government was vulnerable on these grounds was largely the reason for the sensitivity of its members and supporters to any slights offered by the former coalitionists, and any manoeuvring on their part. ${ }^{17}$ Although the latter (with the exception of Birkenhead) were temperate in public, their cool detachment was resented; even Austen Chamberlain's half-brother Neville noted that he had 'kept aloof', and that when he did intervene in debate 'there has been a somewhat acid tone about his remarks'. ${ }^{18}$ Even more significantly, it was clear from statements such as Austen Chamberlain's speech at Birmingham in March 1923 that the coalitionists had not changed their minds about the dangers of dividing the 'anti-Socialist forces'. ${ }^{19}$ The belief was 
prevalent amongst MPs 'that there was a Chamberlain cave, pledged to an "all or none" policy inimical to the wider interests of the Party'. ${ }^{20}$ The Coalition grandees' eminence was still assumed, ironically much on their own terms, and re-admitting them would dangerously open the door to a coup from within. For these reasons, whilst reunion was generally desired, there inhibitions against it happening too soon. The coalitionists mistakenly believed 'that time will show without our aid that we were right', when in fact with each month that the government remained in office, the less necessary and more out-of-touch the former leaders appeared. ${ }^{21}$

The exiled coalitionists were well aware that Law's health was extremely suspect; ${ }^{22}$ they assumed that if he had to retire, their return would become essential and they could almost impose their own terms. When illness forced Law to resign quite suddenly in May 1923, it was natural that the coalitionists should expect his replacement to be the grand and greatly-experienced Foreign Secretary, Lord Curzon. Much as they detested him for his last-minute switch of sides in October $1922,{ }^{23}$ they knew that Curzon operated on the same assumptions about high politics. With his own claim to being Law's inevitable successor resting upon his experience and superiority, he would find it impossible to continue with a cabinet of undistinguished newcomers, and would offer prominent positions to the coalitionists. ${ }^{24}$ When the mantle instead went to Baldwin, it was not just a blow to Curzon but a setback to the coalitionists - and it was known and understood as such in both camps, especially amongst those who had been rebel junior ministers in October 1922, such as Amery and Bridgeman. At this time, Baldwin did not have a strong enough position to bring back the coalitionists as a group, or any intention of doing so. ${ }^{25}$ He sought instead to break up their cohesion, with approaches to the less eminent who would also be less difficult for the Party rank and file to swallow. The leading coalitionists had been meeting regularly as a group, both privately and with occasional public dinners, ${ }^{26}$ but on Law's retirement Austen Chamberlain formally released his colleagues from any obligation to remain together and refuse office. ${ }^{27}$ However, the combination of their pride, resentment and mutual esprit de corps kept nearly all of them together voluntarily. Horne refused the offer of a return to the Treasury (vacated by Baldwin when he became Prime Minister), ${ }^{28}$ and only the lightest-weight of the coalitionist leaders took the bait. For some time, Worthington-Evans had been thought by the others to be eager to return to office, ${ }^{29}$ but his swallowing of such a small fly as the Postmaster-Generalship only made him seem foolish and greedy to both sides - the phrase 'worthy reasons' becoming a euphemism for unprincipled selfseeking. Baldwin did make an approach to Austen Chamberlain when the latter returned from the continent a few days later, but deeply offended him with the offer the Washington embassy, which would have removed him from public life. ${ }^{30}$ Whether Baldwin's lack of tact and enthusiasm were deliberate or not, they certainly reflected political reality and achieved more or less the outcome 
which he needed. He had made some offers and gestures for unity, so the blame for continued division rested solely with the coalitionists and appeared to be based upon pride and arrogance, and there was also some disruption and loss of prestige for the coalitionists due to Worthington-Evans's detachment.

The most important figure amongst the coalitionists was Austen Chamberlain, not only because he was the former Party Leader and the leader of the exiles, but also because his character was respected. His return, provided he could accept the status quo, was the one most desired by the anti-coalitionists. However, there were two impediments. First, Chamberlain nursed an understandable grievance against Law for having delivered the fatal blow at the Carlton Club meeting, and more particularly for what Chamberlain regarded as the discourtesy, if not dishonourableness, of not having intimated that he was going to attend. ${ }^{31}$ For this reason, he felt unable to serve under Law again, and so declined the offer of the Lord Privy Seal in April 1923, despite the clear message that it was intended to position him to be Law's successor. ${ }^{32}$ This barrier was removed when Law resigned in May, but the other and more difficult issue vexed matters for another eighteen months. This was Austen Chamberlain's sense of specific obligation to Birkenhead, and his refusal to return unless a place was found for the latter as well. It was implicit that other coalitionist figures such as Horne and Worthington-Evans would also return (Balfour's age leaving him rather out of the picture), but it had to be made explicit in Birkenhead's case because of the intense hostility towards him. Chamberlain's 'perverted sense of loyalty' was to prove a repeated stumbling block, made greater due to Birkenhead's combativeness. ${ }^{33}$ As Ronald McNeill, a respected junior minister, noted in November 1923: 'His proceedings since Bonar took office has alienated people even more than anything that happened during the Coalition., ${ }^{34}$ Birkenhead's personal conduct, and public events such as his notorious Rectoral Address at Glasgow University in November 1923, led to his being considered an electoral liability, especially with the new women voters. ${ }^{35}$ His tendency to boastful indiscretion in personal conversations also did him harm; one typical incident with the diehard MP Basil Peto and former Party Chairman George Younger, figures hardly sympathetic to coalitionism, led the former to conclude that Birkenhead was 'simply trying to blackmail the P.M.' for a place in the cabinet. ${ }^{36}$ By the time of the 1923 general election, Davidson warned that 'the present Second Eleven feel exactly the same way as the Second Eleven of last autumn felt towards F.E. [Birkenhead]' ${ }^{37}$ A few days later, Davidson discovered at his adoption meeting in Hemel Hempstead the extent and vehemence of grass-roots antagonism to Birkenhead. ${ }^{38}$

During the year of division after the 1922 general election, the coalitionists were in the difficult position of hoping for the government to make a blunder. However, when the protectionist 
policy launched by Baldwin at the Party conference in October 1923 destabilised the government's position, the coalitionists were unable exploit the opportunity and instead found themselves swept away in the tide. The view that achieving this result was Baldwin's primary purpose in adopting tariffs has for some time been discredited, and it is clear that the worsening unemployment situation together with the weak position of the government were the driving forces. ${ }^{39}$ However, although it was a decade later when Baldwin told Tom Jones that his motive had been to separate the Conservative coalitionists from Lloyd George, this does not mean it was not a contributory element and a dividend worth obtaining. ${ }^{40}$ Ministers were constantly anxious that Lloyd George was going to pull the rug from under their feet, and rumours were circulating in early October that he and Birkenhead were going to declare for protectionism as a means of restoring the Coalition. ${ }^{41}$ On 12 November, the day on which the King agreed to a dissolution, Baldwin met Austen Chamberlain and Birkenhead to explore possible reunion. The coalitionists failed to appreciate how their position had weakened in the last six months, and asked too high a price: the inclusion most of their group, and for the two principals ministerial posts after the election that were 'on the same footing of influence and authority as we had previously held'. ${ }^{42}$ Baldwin briefly appeared to accept this, but resistance from Amery and Lord Salisbury gave him a perhaps not unwelcome reason for letting the negotiation lapse. Although they were not given office, Austen Chamberlain's and Birkenhead's past support for tariff reform left them no credible alternative to publicly supporting Baldwin, and their platform efforts during the campaign went some way to rehabilitate them with mainstream Party opinion.

The election took place on 6 December 1923, and was a clear rejection of the tariff policy. The Conservatives lost their overall majority, but were the largest party with 258 MPs to the 191 Labour and 158 Liberal Members. In the week after the poll, a plot was launched by Birkenhead to replace Baldwin with a leader who could come to an arrangement with the Liberals and prevent Labour taking office, but this plan collapsed when it became clear that he had misrepresented Balfour's position and had misled Derby and others. ${ }^{43}$ On 11 December, the cabinet unanimously endorsed Baldwin's strategy of remaining in office until the new Parliament met in late January, thus making the Liberal Party responsible for installing a Socialist government in office. There was much complaint within the Conservative Party over the calling of the election and the defeat, but almost none of the critics wanted Baldwin to depart; the leading diehards were far from alone in concluding that 'it would be fatal to abandon Baldwin'. ${ }^{44}$ This was partly because his public image made him an asset, but also because the most likely replacements were coalitionists. Anticoalitionism was crucial in Baldwin's survival, and the rumours of intrigue against him produced a 'very marked' rally of support from mainstream MPs. ${ }^{45}$ Baldwin remained the most acceptable 
leader, and his continued presence was seen by the majority as a guarantee of the Party's independence and integrity. ${ }^{46}$ Ormsby-Gore's view of the lesser evil was widely shared: he 'would far rather have a Labour government' than restore the dominance of Lloyd George or the coalitionists. $^{47}$ After six weeks of fevered speculation, any possibility of a revived coalition was ended on 21 January 1924, when the Liberal and Labour parties combined to vote the government out of office. Following this, there was little opposition in the Shadow Cabinet to the return of the coalitionists, and agreement that it was better to accept Birkenhead in order to secure Austen Chamberlain and achieve unity. ${ }^{48}$ Being in opposition made this easier; the exiles were not being given ministerial office, and there was no need to drop anyone to make room for them. With Neville Chamberlain's mediation and advice, Baldwin dined with Austen Chamberlain on 5 February and extended an invitation for the coalitionists to return to the front bench in a form tactful enough for it to be accepted. ${ }^{49}$

\section{III}

Reunion in body, if not in spirit, occurred with the return to the front bench and Shadow Cabinet on 7 February 1924 of Austen Chamberlain, Birkenhead, Balfour and Crawford (Horne being away on business in the United States). In one sense, this took place on Baldwin's terms, but his position had been weakened by the election debacle, which had turned the spotlight directly upon the issues of experience and competence. Austen Chamberlain at once took up a dominant position, beginning at the first shadow cabinet meeting which he attended. The two groups were still uneasy with each other, due to two sources of friction which were to be constant for the next several years: on the one hand, the thin-skinned insecurities of the anti-coalitionists, and on the other, the superior and condescending manner of the coalitionists - a habit of mind acquired before the Coalition fell (and in no small part a contributor to its decline), and persisted in perhaps because pride had been all there was to sustain the dispossessed leaders in their uncomfortable exile. Thus, Birkenhead was reported in October 1924 as claiming that with reunion Baldwin 'will be well under control' in a future cabinet, an expectation bound to alarm the anti-coalitionists. ${ }^{50}$ The Olympian presumptions of the coalitionists led them to under-estimate their colleagues from the Prime Minister downwards, and thus to be surprised when any of them did well. After two years in the cabinet of Baldwin's second ministry, Birkenhead was reported in dinner conversation to have described one colleague (Sir John Gilmour) as 'surprisingly good', and in the case of another (William Bridgeman) to admit 'that he had completely under-rated him. ${ }^{, 51}$ The ex-coalitionists tended to socialise more with each 
other than with their newer and sometimes younger colleagues; this was particularly the case with Churchill and Birkenhead, who were close friends, but also included Balfour, Horne and, to a lesser extent, Austen Chamberlain. ${ }^{52}$ Inevitably, their dinner gossip leaked out, and those aspects which denigrated their colleagues or hinted at a hankering for coalition received the widest currency. This was sometimes confirmed from unexpected quarters: in January 1924, Amery was told by his incoming Labour successor as First Lord of the Admiralty that Birkenhead, Beaverbrook and others 'were still intriguing' with Lloyd George. ${ }^{53}$

Reunion therefore did not end the resentments and suspicions, although over time - especially after the return to office in November 1924 - their virulence and frequency diminished. The conflict changed from being one between two publicly separated camps into a fault-line within the leadership, less visible but certainly not forgotten. After Curzon's death in 1925, the leader of the unofficial body of independent Conservative peers warned Baldwin that Birkenhead would be an unsuitable successor as Leader of the Party in the House of Lords because he 'still suffers Coalition reminiscences'. 54 For two reasons, the fire still smouldered and any careless stirring of the ashes would swiftly rekindle the flames. Firstly, the coalitionists seemed to have set aside their crossparty inclinations temporarily rather than permanently, and such incidents as unnecessary compliments to Lloyd George in a speech of Austen Chamberlain's at once raised hackles. ${ }^{55}$ In August 1924, Neville Chamberlain sounded a respected junior minister of the 1922-24 ministry to get an understanding of the way in which his half-brother was regarded, and was told that older backbenchers considered Austen 'a Coalitionist still in mind though he might have given it up in practice'. 56

Secondly, the anti-coalitionists held a particular view (which was not shared by the other side) of what the dispute had been about in 1922 - nothing less than the heart and soul of the Conservative Party. The anti-coalitionists believed that they had rallied to the defence of principle against opportunism, clean politics against corruption. The coalitionist leaders might think that what counted was brains and experience, but the rebels were far closer to the ethos of Conservatism in prizing character - particularly in the forms of honesty, consistency and straightforwardness above this. ${ }^{57}$ The most effective rejoinder to Birkenhead's jibe about 'second-class brains' had been Lord Robert Cecil's reply that this was better than having 'second-class characters'. The standard-bearer of this purified politics, in his own eyes and those of many others, was Baldwin; as one MP wrote in the autumn of 1924, 'we see you struggling courageously to raise the level of British Conservatism'. ${ }^{58}$ Defending Baldwin's leadership was more than supporting one man against another; when he was under attack from the press lords in 1930, one mainstream MP was moved to declare that 'to my way of thinking Mr. Baldwin stands for all that is vital, fundamental 
and true for the progress and development of civilisation not only in the Empire but all over the world'.59

Only a few weeks after reunion, the submerged antagonisms and suspicions were revived by Churchill's contesting of the Westminster Abbey by-election in March 1924 as an 'Independent Anti-Socialist' candidate, although there was also an official Conservative candidate nominated by the local association. Churchill's transition back to the Conservative Party was actively promoted by the former Coalition leaders, and the darkest interpretations were placed on their motives. It was assumed by anti-coalitionists that it was an attempt to reinforce the coalitionist faction as the prelude to an internal conspiracy and coup. ${ }^{60}$ For the editor of the strongly-Conservative Morning Post newspaper, the issue was stark: Gwynne told Baldwin that 'if the other side win, you will go and with you all that is fine in our party will disappear', whilst the triumph of the coalitionist strategy would swiftly result in 'giving the country over to Socialism'. ${ }^{61}$ Baldwin had to juggle a potentially explosive clash between the returned coalitionists, who wished to support Churchill publicly (with Austen Chamberlain particularly vehement), and anti-coalitionist front-benchers such as Amery, who rallied to the official candidate. He was able to appease both sides and seem impartial, and outcome was a fortunate one of a narrow victory for the official Conservative with Churchill a handful of votes behind. Even so, the affair had given the flimsy reunion a bad shake, and another event a few weeks later indicated that all was far from being happy families in the Shadow Cabinet.

On 18 May 1924, an interview with Baldwin was published in The People newspaper which contained unprecedently pointed aspersions on the former coalitionists and related targets, such as the press barons Beaverbrook and Rothermere. In many eyes, the latter were tarred with the brush of coalitionism: they were seen as unprincipled and unscrupulous, keen to fish in muddied waters, and their ministerial offices in 1917-18 were considered one of the worse excrescences of the Coalition; they were close to the coalition-minded, such as Churchill and Birkenhead (who earned money writing for their newspapers), and both Beaverbrook and - particularly - Rothermere were in regular contact with Lloyd George. Baldwin almost certainly did not intended his comments to appear in this way, and had to write letters denying them to the injured parties. However, this maladroitness was not the important point, which is that the interview exposed the continuing suspicion and ill-feeling within the leadership, and was a warning shot against a combination who might attempt a coup. Matters did improve in the next few months as the political situation became more favourable, with Liberal disarray and mistakes from the Labour government. As the Labour government fell in October, an MP who had supported Churchill in the Abbey by-election, and later regretted his action, wrote to warn Baldwin of 'forces in our Party (rapidly diminishing I 
think) which are working against you., ${ }^{62}$

The landslide Conservative victory of 1924, with 412 MPs elected, validated the overthrow of the Coalition by proving that the Party could stand alone in the democratic era and win conclusively. Baldwin's position was enormously strengthened, and he cemented the reunion by giving prestigious posts to the principal coalitionists, although ones which would keep them apart from each other and distanced from the most sensitive areas of domestic politics. ${ }^{63}$ Austen Chamberlain became Foreign Secretary, Birkenhead went to the India Office and, in the most unexpected move, Churchill was made Chancellor of the Exchequer. However, Baldwin seems to have deliberately excluded Horne, by offering the comparatively junior Ministry of Labour in such a way as to suggest he did not want him at all. Bringing the other coalitionists into such important offices caused some alarm amongst junior ministers and backbenchers, with the 'diehard' leader John Gretton warning Baldwin: 'I am sure the Coalition idea is not yet dead and the "Brains" still hanker after a centre party' ${ }^{64}$ Suspicion was not confined to the reactionary or obscure, and the rising junior minister William Ormsby-Gore worried that 'knowing how Birkenhead and Winston dislike Baldwin, one fears that these pushing men may try to play for their own hand' ${ }^{65}$

Such fears soon seemed to be borne out in the 'cruiser crisis' of early 1925. This was a simple, although severe, case of conflict between the Treasury and a spending department from which it was seeking economies. What made this politically sensitive was firstly that the Chancellor of the Exchequer was the recently-returned Winston Churchill, a former Liberal who seemed to personify coalitionism, whilst the First Lord of the Admiralty was William Bridgeman, a key figure amongst the rebel junior ministers of 1922 and a close friend of Baldwin. An even closer aide and confidant of the Prime Minister, J.C.C. Davidson, was serving as a junior minister at the Admiralty, and he at once took this to be a coalitionist intrigue, and told Baldwin so. ${ }^{66} \mathrm{He}$ was far from alone: the gossip in the House of Commons was that it was a plot to force out Bridgeman and make room for Horne, in order 'to strengthen the Coalition element in the Cabinet', and it is significant that even a newly-elected MP saw the crisis in these terms. ${ }^{67}$ Bridgeman was less specific, but with his back to the wall in the later stages of the crisis, his memo setting out the 'political case for the Admiralty' pointedly observed that 'the most loyal part of the Conservative Party' supported the navy's building programme, and that if Baldwin lost this constituency he would have no solid body of support to rely upon. ${ }^{68}$ Following this, Churchill - who had been sure he was about to triumph - found himself instead to be the loser of the battle.

As the government continued, and especially after the baptism of fire of the General Strike in 1926, the cabinet grew accustomed to working together and mutual regard developed, sometimes unexpectedly. ${ }^{69}$ When Birkenhead departed in 1928 for personal reasons, his resignation letter 
observed that a cabinet 'which assembled upon the crater of some bitter and recent memories' had become 'a band of brothers'. ${ }^{70}$ The lines of disagreement varied from issue to issue and were not repeatedly drawn upon pro- and anti-coalition lines, and there was no accusation from within the cabinet of the coalitionists acting as an organised faction. However, suspicion was only submerged, and resurfaced at any hint of intrigue or a change in the political balance. The victors of 1922 had a lingering belief that the ex-coalitionists could be easily tempted into their old habits; like an alcoholic, they might be abstaining for the present, but the weakness remained. The anticoalitionists believed that Lloyd George still exerted a fascination for his former lieutenants, and assumed that more was going on behind the scenes than was apparent. ${ }^{71}$ There were enough rumours, loose talk and minor incidents to give this credence, although this was often a matter of interpretation (or misinterpretation). Churchill was habitually indiscreet, talking loosely at one point in 1927 of the possibility of Lloyd George joining the government. ${ }^{72}$ After Birkenhead left the cabinet to earn money in the City, he also resumed his profitable newspaper articles; inevitably, Davidson's suspicions were aroused, darkly observing that 'the hair on his heels becomes a little more visible and a little thicker every day. ${ }^{, 73}$ Davidson was always conscious of the dividing line drawn in 1922, and 'continuously' pointed out to Baldwin the ambitions, 'sense of superiority and indispensability' of the coalitionists. ${ }^{74}$ This may have contributed to Baldwin's sentiment, voiced as late as 1928, that 'he could never feel quite safe with men who had been L.G.'s men'. ${ }^{75}$

Following the defeat in the 1929 general election, with the Liberals again holding the balance, there was some backbench alarm that a coalitionist strategy might be adopted. However, the former Coalition leaders were now an ageing and dwindling band: Birkenhead had left the cabinet, Balfour was very elderly, Austen Chamberlain had been seriously ill and was remote from domestic affairs, and Worthington-Evans now carried little weight. Churchill, still active and vigorous, was alone in pressing for negotiation with Lloyd George, but he was also seen a something of a fading force due to criticisms of his tenure of the Treasury and the unpopularity of his free trade views. All these figures, together with some others of the former cabinet, were identified as the 'old gang' whom many mainstream MPs wished to see dropped. ${ }^{76}$ They were still tagged with their Coalition identity, at least in the eyes of the diehards, who's leaders wished 'to scrap the three former Coalition front benchers, as useless, Austen, Winston and Worthy'. ${ }^{77}$ However, Baldwin survived the attacks upon him during 1930-31, and when the Labour government fell in August 1931 many of the 'old gang' were still in the Shadow Cabinet - although not Churchill, who resigned in January 1931 in disagreement with Baldwin's moderate India policy.

It was India which produced one of the last crises in Conservative politics to be largely 
determined by suspicions of coalitionist plots. In October 1929, without much consultation with his colleagues, Baldwin supported the declaration made by the Viceroy, Lord Irwin, that the aim of British policy was eventual Dominion status for India. The negative reaction to this extended across much of the Conservative Party, but because of the attacks on Baldwin by Lord Rothermere's newspapers and the prominent parts taken in the debates in the Lords and Commons by Birkenhead and Lloyd George respectively, there was a rally of support to Baldwin due to the belief that what was happening was, in the words of Geoffrey Dawson, the editor of The Times, 'at bottom a relic of the old Coalition intrigue'. ${ }^{78}$ Davidson had no doubt that the criticism was a plot to undermine Baldwin on the part of 'those in our Party ... whose sympathies are clearly Coalition in character'. ${ }^{79}$ This was given weight by Austen Chamberlain's unhappiness with Baldwin's line, and Churchill's almost open dissent during the highly-charged debate. Significantly, when Dawson described events to the Viceroy, he did not mention policy disagreements but that Chamberlain 'has always hankered after the Coalition' ${ }^{80}$ The view of Cunliffe-Lister, Churchill's cabinet colleague in 1924-29, was 'that Winston seized on the opportunity to make common cause with L.G.', and 'seems resolved on reunion with Rome at any cost'. ${ }^{81}$ Winterton was far from alone from giving credence to the 'circumstantial rumours' that, as he revealingly described, 'some nominal members of our Party' were intriguing with Rothermere and Lloyd George to achieve the dual aim of Baldwin's downfall and 'a new Coalition'. ${ }^{82}$ This was jumping at shadows: the issue was not coalition, but what it actually appeared to be - India. Differences on this ran across party boundaries and within parties, with Liberals such as Lloyd George and the former Viceroy, Lord Reading, sharing doubts about Irwin's policy not only with Churchill, Austen Chamberlain and Birkenhead, but also with Lord Salisbury and the Conservative right-wing. Baldwin's endorsement of Irwin (whom he had appointed as Viceroy in 1925) and his non-partisan support for the Labour government's policy dismayed many more Conservatives across the party spectrum than just former coalitionists. For Davidson to see the parliamentary debates on the Irwin Declaration in this distorted light is perhaps predictable and dismissible - but that more level-headed figures such as Cunliffe-Lister and Dawson should so is revealing of which shadows were still the longest and darkest, even seven years after the fall of the Coalition.

Anti-coalitionism also played a part in sustaining Baldwin's leadership during the internal crisis of 1930-31. The assault by the press lords was seen as associated with a revived form of coalition, as Rothermere would support a replacement leader - such as Horne - who would cut a deal with Lloyd George and get the Labour government out of office. For most Conservative MPs, as in 1924, that was not a price worth paying. When Baldwin came to the brink of resignation in March 1931, there were four possible successors: two coalitionists (Horne and Churchill) and two 
anti-coalitionists (Hailsham and Neville Chamberlain). It was no coincidence that the two latter came to an understanding to co-operate rather than compete, due to their over-riding desire to ensure the leadership did not fall into the hands of either of the former coalitionists. ${ }^{83}$ In 1930-31 death removed the figures of Balfour, Birkenhead and Worthington-Evans, whilst after the 1931 election it was clear that Austen Chamberlain and Horne would not hold office again. The last senior coalitionist to retain credible ambitions for power beyond 1931 was Churchill, and the final coda of the coalition's legacy was the continuing distrust with which he was regarded in the 1930s. The effectiveness of his India campaign was always hampered by suspicions that it was just a pretext for an attempt to smash the National Government and seize the Party leadership, 'to play cuckoo using India for this purpose. ${ }^{84}$

In the long term, the anti-coalitionists won as conclusively as they had in 1922. By the 1930s, Disraeli's dictum that 'England does not love coalitions' had become an article of faith within the Conservative Party. ${ }^{85}$ Even in the hung parliaments of the first and second Labour Governments in 1924 and 1929-31, the line was held that no concessions on policy or electoral reform would be given to secure Liberal support in defeating the government; significantly, the only such pact at national level, with Sir John Simon's group in 1931, was explicitly based on their acceptance of the Conservative protectionist programme. Fusion with any other party to create a new centre party was ruled out; whatever the National Government began as or evolved into, it was never that. Entry into a new coalition in August 1931 was unplanned, and came about due to the extreme pressures and peculiar topography of the crisis. The proviso that it was to be temporary and not affect party compositions or programmes was written into its founding agreement entirely to reassure the Conservative Party, and Baldwin emphasised that there had been no loss of autonomy or sacrifice of principle at the party meeting called a few days later. ${ }^{86}$ The unfolding difficulties of coping with the crisis led to the necessity of the government staying together and proving that it had a mandate, and thus to the general election of October 1931.

The National Government remained an uneasy affair until the departure of the free-trade Samuelite Liberals in September 1932; after this it continued more comfortably because it was significantly unlike the nature of, and balance of powers within, the Lloyd George government of 1918-22. It was not that it was, as cruder and older historiography portrayed, a Tory ministry hiding behind sham front to deceive the unwary voters; the non-Conservative element had considerable representation and real power in the cabinet, and policies in many areas differed from what a purely Conservative administration would have been likely to chose. Rather, it was more an association of leaders than of parties: Ramsay MacDonald might be Prime Minister, but he had only a handful of MPs in his following, and whilst the Simonite group was a little larger, its 
significance lay in the prestige and competence of its leading figures and the Liberal votes which their endorsement would bring to Conservative candidates standing under the National banner. It is these differences which explain how the Conservative anti-coalitionists who rose to the leadership in 1922 worked within the National Government from 1931 to 1940 without seeing this as inconsistent or hypocritical. The Chief Whip of that period, David Margesson, saw no reason to retract the view he had expressed to the selection committee of the Rugby constituency in February 1924, that coalitions 'always led to a sacrifice of principles'. ${ }^{87}$ It was not that he had abandoned his principles, or even that National Labour and Liberal National leaders had abandoned theirs (though they had certainly changed some views, principally on free trade). It was that the National Government was not 'coalition' like that of 1918-22 in its ethos, conduct or (crucially) effectiveness, and so it was possible to be within it without eroding Party identity and vitality or losing self-respect. Thus, after 1931 the Conservative Party remained well-organised, wellresourced, active and cohesive, whilst still affirming the mantra that coalition was an anema to be avoided in peacetime.

\section{REFERENCE LIST}

Ball, S. Baldwin and the Conservative Party: The Crisis of 1929-1931. New Haven \& London: Yale University Press, 1988.

---, ed. Parliament and Politics in the Age of Baldwin and MacDonald: the Headlam Diaries 19231935. London: The Historians' Press, 1992.

Barnes, J. \& Nicholson, D., eds. The Leo Amery Diaries, Volume 1: 1899-1929. London: Hutchinson, 1980.

Campbell, J. F.E. Smith, 1st Earl of Birkenhead . London: Jonathan Cape, 1983.

Close, D.H. 'Conservatives and Coalition after the First World War'. Journal of Modern History 45 (1973): 240-260.

Cowling, M., The Impact of Labour 1920-1924. Cambridge: Cambridge University Press, 1971.

Dutton, D., Austen Chamberlain. Bolton: Ross Anderson, 1985.

James, R.R., ed. Memoirs of a Conservative: J.C.C. Davidson's Memoirs and Papers 1910-1937. London: Weidenfeld and Nicolson, 1969.

Jones, T. Lord Baldwin: A Memoir. London: Times Newspapers, 1947.

Kinnear, M. The Fall of Lloyd George. London: Macmillan, 1973.

Ramsden, J. The Age of Balfour and Baldwin 1902-1940. London: Longman, 1978. ---, ed. Real Old Tory Politics: The Political Diaries of Sir Robert Sanders, Lord Bayford: 1910- 
1935. London: The Historians’ Press, 1984.

Riddell, Lord. Lord Riddell's Intimate Diary of the Peace Conference and After 1918-1923. London: Gollancz, 1933.

Self, R. 'Conservative reunion and the general election of 1923: a reassessment'. 20th Century British History 3, no. 3 (1992): 249-273.

---, ed. The Austen Chamberlain Diary Letters [ACDL]. Cambridge: Royal Historical Society, 1995.

---, ed. The Neville Chamberlain Diary Letters: Volume 2, The Reform Years 1921-1927 [NCDL]. Aldershot: Ashgate, 2000.

Vincent, J., ed. The Crawford Papers. Manchester: Manchester University Press, 1984.

1 Cowling, Impact of Labour; Ramsden, Age of Balfour and Baldwin, 166-207; Close, 'Conservatives and Coalition', 256-60.

$2 \quad$ Kinnear, Fall of Lloyd George, 208-9.

3 Eyres-Monsell to Baldwin, 25 May 1928, Baldwin MSS (Cambridge University Library), $163 / 201$.

Eyres-Monsell to Baldwin, 6 Nov. 1925, Baldwin MSS, 160/55.

Bridgeman to Irwin, 15 June 1930, Halifax MSS (British Library), EUR.C.152/19/1/79.

Austen to Hilda Chamberlain, 18 Nov. 1922, to Ida, 24 Feb. 1923, Self, Austen

Chamberlain Diary Letters [hereafter $A C D L], 201,220$. Austen to Hilda Chamberlain, 4 Mar. 1923, ACDL, 221. Bayford diary, 2 Mar. 1923, Ramsden, Real Old Tory Politics, 201.

Amongst those who changed tack following the Carlton Club meeting was George Tryon, who thus avoided a hostile candidate being nominated against him: Lady Peto diary (courtesy of Mr J. Peto, Woodbridge, Suffolk), 23 Oct. 1922. Ramsden, Age of Balfour and Baldwin, 168. Storr to Davidson, 14 Aug. 1923, Davidson MSS (Parliamentary Archives), 159. Crawford diary, 17 Nov. 1922, Vincent, Crawford Papers, 467; Austen to Ida Chamberlain, 21 Nov. 1922, $A C D L, 208-9$

Birkenhead's comments to Pollock on 22 Oct. 1922, recorded in 'The Fall of the Coalition Government under Lloyd George in October 1922', n.d. but c. Sep. 1931, Hanworth MSS (Bodleian Library); Riddell diary, 15 Jan. 1923, Lord Riddell's Intimate Diary of the Peace Conference, 400. Campbell, F.E. Smith, 612-7. 
Birkenhead had expected an inconclusive outcome which would make renewed coalition inevitable: Winterton to Lytton, 22 Nov. 1922, Lytton MSS (British Library), EUR.F.160/26/8-13.

Austen Chamberlain to Lloyd, 7 Dec. 1922, Austen Chamberlain MSS (Birmingham University Library), AC/18/1/35.

Amery diary, 17 Apr. 1923, Barnes \& Nicholson, Leo Amery Diaries, Volume 1, 324.

Necille to Ida Chamberlain, 26 May 1923, Self, Neville Chamberlain Diary Letters: Volume 2,163 .

Dutton, Austen Chamberlain, 201.

Worthington-Evans, memo of events of May 1923, n.d., Worthington-Evans MSS

(Bodleian Library), Eng. Hist. c.894/50.

Austen to Ida Chamberlain, 21 Nov. 1922, ACDL, 209.

Austen to Ida Chamberlain, 21 Nov. 1922, ACDL, 208; Winterton to Lytton, 11 July 1923, Lytton MSS, EUR.F.160/26/15-24.

Derby diary, 23 Nov. 1922, 28 Apr. \& 1 May 1923, Derby MSS (Liverpool Record Office), $\operatorname{DER}(17) / 29 / 1$.

Curzon to Austen Chamberlain, 28 May 1923, Curzon MSS (British Library), EUR.F.112/320.

Worthington-Evans, memo of events of May 1923, n.d., Worthington-Evans MSS, Eng. Hist. c. $894 / 46$.

Austen to Ida Chamberlain, 3 Dec. 1922, ACDL, 216.

Austen Chamberlain to Worthington-Evans, telegram and letter, 24 May 1923, Worthington-Evans MSS, Eng. Hist. c.894/15-21.

Worthington-Evans, memo of events of May 1923, n.d., Worthington-Evans MSS, Eng. Hist. c.894/45; Horne to Baldwin, 25 May 1923, Baldwin MSS, 42/29-30.

Austen to Ida Chamberlain, 10 Mar. 1923, ACDL, 223.

Neville Chamberlain diary, 1 June 1923, Neville Chamberlain MSS (Birmingham University Library), NC/2/21.

Austen to Ida Chamberlain, 18 Nov. 1922, $A C D L, 202$, noting that Balfour had condemned Law's action 'as one of "those things that gentlemen don't do"”; Austen to Ida Chamberlain, 10 Mar. 1923, ACDL, 223-4; Austen to Neville Chamberlain, 25 Apr. 1923, Neville Chamberlain MSS, NC/1/27/71.

Austen to Hilda Chamberlain, 14 Apr. 1923, ACDL, 227.

Ormsby-Gore to Baldwin, 29 Jan. 1924, Baldwin MSS, 42/182-7. 
McNeill to Baldwin, 12 Nov. 1923, Baldwin MSS, 42/133-4; for an example of rank and file hostility, see Headlam diary, 8 Jan. 1924, Ball, Parliament and Politics in the Age of Baldwin and MacDonald, 37.

Report of Central Office opinion in Memo by Davidson \& Herbert, 14 Nov. 1923, OrmsbyGore to Baldwin, 29 Jan. 1924, Baldwin MSS, 42/130-1 \& 182-7.

Lady Peto diary, 17 Nov. 1923.

Memo by Davidson \& Herbert, to Baldwin, 14 Nov. 1923, Baldwin MSS, 42/130-1.

Davidson to Jackson, 18 Nov. 1923, Davidson MSS.

R. Self, 'Conservative reunion and the general election of 1923: a reassessment', 20th Century British History, 3, no. 3 (1992), 250-60.

Jones, Lord Baldwin, 8.

Bayford diary, 11 Oct. 1923, 209; James, Memoirs of a Conservative, 184-5.

Austen Chamberlain's note of meeting with Baldwin on 12 Nov. 1923, 13 Oct. 1923, AC/35/3/21b; Austen to Hilda Chamberlain, 14 Nov. 1923, ACDL, 236.

Derby diary, 10 \& 11 Dec. 1923, Derby MSS, DER(17)/29/1; Worthington-Evans, memo of events of 22 Oct. 1923 to 3 Jan. 1924, n.d., Worthington-Evans MSS, Eng. Hist. c.894/5778.

Gretton to Croft, 4 Feb. 1924, Croft MSS (Churchill College, Cambridge), CRFT/1/12/GR1.

Derby to Birkenhead, 11 Dec. 1923 (not sent), Derby MSS, DER(17)/29/1; Ormsby-Gore to Davidson, 9 Dec. 1923, Norton-Griffiths to Davidson, 12 Dec. 1923, Davidson MSS, 168. Bridgeman to Baldwin, 8 Dec. 1923, Amery to Baldwin, 8 Dec. 1923, Strachey to Baldwin, n.d. but c.9 Dec. 1923, Baldwin MSS, 35/173-4, 169-72, 189.

Ormsby-Gore to Baldwin, 29 Jan. 1924, Malcolm to Baldwin, 7 Dec. 1923, Tryon to Baldwin, 11 Dec. 1923, Baldwin MSS, 42/182-7, 35/168 \& 188.

Neville to Ida Chamberlain, 30 Jan. 1924, NCDL, 206; Cecil to Baldwin, 1 Feb. 1924, Cecil MSS (British Library), Add.51080/113-6.

Neville to Hilda Chamberlain, 9 Feb. 1924, NCDL, 207; Baldwin to Balfour, 6 Feb. 1924, Balfour (Whittingehame) MSS (National Archives of Scotland), GD/433/2/19/31.

Letter reported to have been written by Birkehead, sent by Lady Houston, 31 Oct. 1924, Baldwin MSS, 159/214-7.

Memo by Davidson, conversation at Birkenhead's house, n.d. but c. Nov. 1926, Baldwin MSS, 161/69-71.

For example, Austen to Hilda Chamberlain, 16 Feb. 1924, ACDL, 249. 
Amery diary, 21 Jan. 1924, 366.

Midleton to Baldwin, 28 Mar. 1925, Baldwin MSS, 160/105-6.

Other examples were the difference in tone of Chamberlain's and Baldwin's overtures to disaffected Liberals (Austen to Hilda Chamberlain, 19 July 1924, $A C D L, 255$ ) and Chamberlain's article in the Evening News, 30 July 1924, Ramsden, Age of Balfour and Baldwin, 198.

Neville to Hilda Chamberlain, 17 Aug. 1924, NCDL, 241.

Cecil to Baldwin (copy), 7 Nov. 1923, Templewood MSS (Cambridge University Library), $\mathrm{V} / 1$.

Chadwick to Baldwin, 24 Oct. 1924, Baldwin MSS, 163/81

Smithers to Salisbury, 19 Aug. 1930, Salisbury MSS (Hatfield House), S(4)136/148.

Ormsby-Gore to his mother, 30 Mar. 1924, Brogyntyn MSS (National Library of Wales), $\mathrm{PEC} / 10 / 1 / 12 / 23$.

Gwynne to Baldwin, 7 Mar. 1924, Baldwin MSS, 51/63-4.

Chadwick to Baldwin, 24 Oct. 1924, Baldwin MSS, 163/81

Neville to Hilda Chabmerlain, 4 Oct. 1925, Self, NCDL, 311-2.

Gretton to Baldwin, 1 Nov. 1924, Gwynne to Eyres-Monsell, 30 Oct. 1924, Baldwin MSS, 36/22-24 \& 27-33.

Ormsby-Gore to his mother, 8 Nov. 1924, Brogyntyn MSS, PEC/10/1/12/26.

James, Memoirs of a Conservative, 211, 213, 215.

Headlam diary, 23 July 1925, 68.

Bridgeman memo, 'The Political Case for the Admiralty', n.d. but c. Feb. 1925, Baldwin MSS, 2/70-7.

N. Chamberlain to Irwin, 25 Dec. 1927, Halifax MSS, EUR.C.152/17/1/277a.

Birkenhead to Baldwin, 16 Oct. 1928, Birkenhead MSS (British Library), EUR.D.703/44.

Dawson to Irwin, 31 Oct. 1929, Halifax MSS, C152/18/1/288; Agnes Lane-Fox to Irwin, 17 June 1930, Halifax MSS at Borthwick Institute (University of York), A2/278/6/2.

Davidson to Irwin, 17 Aug. 1927, 'Memo of conversation with Sir W. Berry', 6 Mar. 1929, Davidson MSS, 180, 186.

Davidson to Irwin, 3 Dec. 1928, Halifax MSS, EUR.C.152/18/1/173.

James, Memoirs of a Conservative, 231.

Headlam diary, 9 Feb. 1928, 140.

Ball, Baldwin and the Conservative Party, 159-61.

Lady Peto diary, 22 Feb. 1930. 
Dawson to Irwin, 31 Oct. 1929, Halifax MSS, EUR.C.152/18/1/288.

79 James, Memoirs of a Conservative, 308-10.

80 Dawson to Irwin, 3 Nov. 1929, Halifax MSS, EUR.C.152/18/1/290.

81 Cunliffe-Lister to Irwin, 28 Dec. 1929, Lane-Fox to Irwin, 11 Dec. 1929, Halifax MSS, EUR.C.152/18/1/344, 328 .

82 Winterton to Irwin, 11 Nov. 1929, Halifax MSS, C152/18/1/295.

83 Ball, Baldwin and the Conservative Party, 135-6.

84 Orsmby-Gore to his mother, 9 Mar. 1931, Brogyntyn MSS, PEC/10/1/14/5.

For example, Hoare's comment 'The country hates coalitions', in his monthly newsletter to Chelsea Conservative Association, Jan. 1930, Templewood MSS, VI/1. Ball, Baldwin and the Conservative Party, 173-91.

Rugby Conservative Association, Executive Ctte., 2 Feb. 1924. 